\title{
Tuberculose miliar em bovino - relato de caso
}

Tatiane Rodrigues da Silva ${ }^{[]^{*}}$, Urias Fagner Santos Nascimento ${ }^{[b]}$, João Victor Cardoso Batista ${ }^{[b]}$, Rachel Linvingstone Felizola Soares de Andrade ${ }^{[b]}$

\footnotetext{
${ }^{[a]}$ Hospital Veterinário, Universidade Federal de Campina Grande (UFCG), Patos, PB, Brasil

${ }^{[b]}$ Hospital Veterinário Dr. Vicente Borelli, Faculdade Pio Décimo (FPD), Aracaju, SE, Brasil
}

*Autor correspondente

e-mail: tatianerodrigues.vet@gmail.com

\section{Resumo}

O objetivo deste trabalho é relatar o primeiro caso de tuberculose miliar em bovino no estado de Sergipe, seus achados clínicos e patológicos. 0 animal deu entrada no hospital veterinário da Faculdade Pio Décimo, vindo da cidade de Itaporanga, Sergipe, com histórico de que há dez dias apresentava emagrecimento progressivo e no oitavo dia de evolução clínica começou a apresentar incoordenação e anorexia. Ao exame físico geral, o animal apresentava dificuldade para levantar-se, mioclonias nos membros pélvicos e glândula mamária com consistência endurecida e aumento de tamanho do teto posterior esquerdo. No exame clínico do sistema nervoso foi observado desvio lateral da cabeça, déficit proprioceptivo com dismetria, ataxia, redução do tônus lingual, flacidez de mandíbula, ausência do reflexo de deglutição e compressão da cabeça contra objetos. Foi instituído tratamento para polioencefalomalácia (corticosteroide e tiamina), porém sem resposta terapêutica. 0 quadro clínico agravou-se e o animal foi submetido ao sacrifício com utilização de lidocaína 2\% intratecal e encaminhado para necropsia. Macroscopicamente foi observado nos pulmões, diafragma e linfonodos mediastínicos, múltiplos nódulos amarelados, de tamanhos variados e consistência firme que, ao corte, apresentavam conteúdo amarelado pastoso com aspecto arenoso na periferia. O coração apresentava grande quantidade de líquido serosanguinolento no saco pericárdico com presença de fibrina livre no líquido; o epicárdio encontrava-se aderido e com grande quantidade de material fibrinoso e áreas multifocais granulares amareladas. A glândula mamária apresentava todo o seu parênquima tomado por material cáseo calcárico, comprimindo todo o parênquima glandular. 0 encéfalo apresentava grande quantidade de granulomas distribuídos pela superfície e córtex cerebral. Fígado e rins também apresentavam granulomas. Histologicamente, as lesões nodulares caracterizavam-se pela formação 
de lesão piogranulomatosa caracterizada por uma área central de necrose, rodeada por macrófagos epitelióides, poucos linfócitos e abundantes células gigantes multinucleadas do tipo Lagehans, eximindo áreas multifocais de calcificação no pulmão, fígado, rins, linfonodos mediastínicos, encéfalo e medula espinhal, caracterizando o quadro de tuberculose miliar, confirmado com a coloração de Ziehl Neelsen. Os sinais clínicos apresentados pelo animal, associados aos achados macroscópicos e histopatológicos, permitem afirmar que o caso relatado trata-se de tuberculose miliar. A forma miliar da tuberculose é descrita em condições em que ocorra disseminação hematógena do bacilo, o que leva à formação de lesões granulomatosas muito pequenas e difusas, que atingem não apenas os pulmões, mas diversos outros órgãos. Essa forma é considerada incomum em animais. Em um estudo realizado com 1.735 búfalos abatidos no estado do Pará, a ocorrência deste tipo de tuberculose ocorreu em apenas cinco animais. A tuberculose miliar deve ser considerada no diagnóstico diferencial de enfermidades que acometem o sistema nervoso em bovinos oriundos de rebanhos com elevados índices de animais positivos para tuberculose, reforçando a importância do inquérito a respeito da prevalência desta enfermidade. 